\title{
MACROALGAE DIVERSITY IN CORAL REEFS AT THE WATERS OF TELUK TAMIANG VILLAGE, KOTABARU
}

\author{
${ }^{1}$ Muhammad Ahsin Rifa'i, 'Muhammad Syahdan, and ${ }^{1}$ Hadiratul Kudsiah \\ ${ }^{1}$ Lecturer at Ocean Science Department, Fishery Faculty \\ Lambung Mangkurat University, Banjarbaru, South Kalimantan \\ Email: m.ahsinrifai@unlam.ac.id \\ ${ }^{2}$ Lecturer at Aquatic Resource Management Department, Ocean Science and Fishery Faculty \\ Hasanuddin University, Makassar, South Sulawesi
}

\begin{abstract}
The purpose of this study was to map the distribution of macroalgae at the waters of Teluk Tamiang Village, Kotabaru, South Kalimantan. The results showed that there were 8 species of macroalgae living in coral reef ecosystems. They originated from 7 order, 8 family, 8 genera, consisting of Acanthopora muscoides, Gracilaria coronopifolia, Amphiroa fragillissima Chlorodesmis sp., Halimeda macroloba, Enteromorpha sp., Turbinaria conoides, and Dictyota pinnatifida. The diversity index of two stations observed in this study was low.
\end{abstract}

Keywords: coral reefs, diversity, macroalgae, Teluk Tamiang

\section{INTRODUCTION}

Macroalgae is one of the main communities in coral reef ecosystems as biotic reef. Algae have the roles as builders and destroyers of coral reef ecosystems (Hughes, 1994). The role of macroalgae is a primary producer to produce food at lower tropic level (Odum, 1971)). The main function of macroalgae is as a source of protein-rich food for marine organisms because it is the only plant with a complete amino acid structure. It is also a provider of carbonate and base substrate strengthener beneficial to the stability and the sustainability of coral reefs. On the other hand, an increase in the amount of nutrients that enter the waters towards the increased primary productivity can trigger the growth of macroalgae, which in turn indirectly affect the coral reefs. The indirect effect is in the form of space competition (Mc Cook et al., 2001).

Red algae and brown algae of the genus focus, often called seaweed are very suitable in the covered intertidal area, especially on rocky beaches. A small number of macroalgae are found attached to the muddy and sandy substrate base. They mostly live and attach to a hard object that is quite solid. They are commonly found attached to reefs, rocks, pieces of coral, mollusk shells, pieces of wood and so on. (Hutabarat \& Evans, 1985). Many types of macroalgae adapt to different types of substrates. The types that occupy a sandy substrate generally have a habitat with a hard (rocky) substrate and "Holdfast" that is well developed, branched or discoidal called "hapter". Such "holdfast" grips the substrate tightly and generally is found in areas that have strong current. Macroalgae can be classified into three divisions based on the content of photosynthetic pigments and pigment accessories, namely Rhodophyta, Phaeophyta and Chlorophyta.

Mature coral reef ecosystems continue to be degraded. The increase in the number of nutrients into the water, and the increase in cover of no coralline algae and filament algae caused by the impact of rising temperatures due to climate change resulting in a process of coral bleaching, sedimentation, and eutrophication (McCook 1999; McCook et al., 2001; Costa Jr. et al., 2008; Renken \& Mumby, 2009; Lapointe et al., 2005).

The waters of Teluk Tamiang Village has a diversity of macroalgae, especially in the area of coral reefs suffering physical and natural damages. Information related to the presence of macroalgae in this water is still very limited. The purpose of this study was to find out the diversity of macroalgae and its relationship with the quality of environment. It is expected that the study could be useful for the rehabilitation of coral reef areas on the basis of ecology and economy. 


\section{MATERIALS AND METHODS}

The study was conducted in May-August 2016 in a reef coral area at the waters of Teluk
Tamiang Village, Pulau Laut Kepulauan Subdistrict, Kotabaru Regency, South Kalimantan Province, presented in Figure 1.

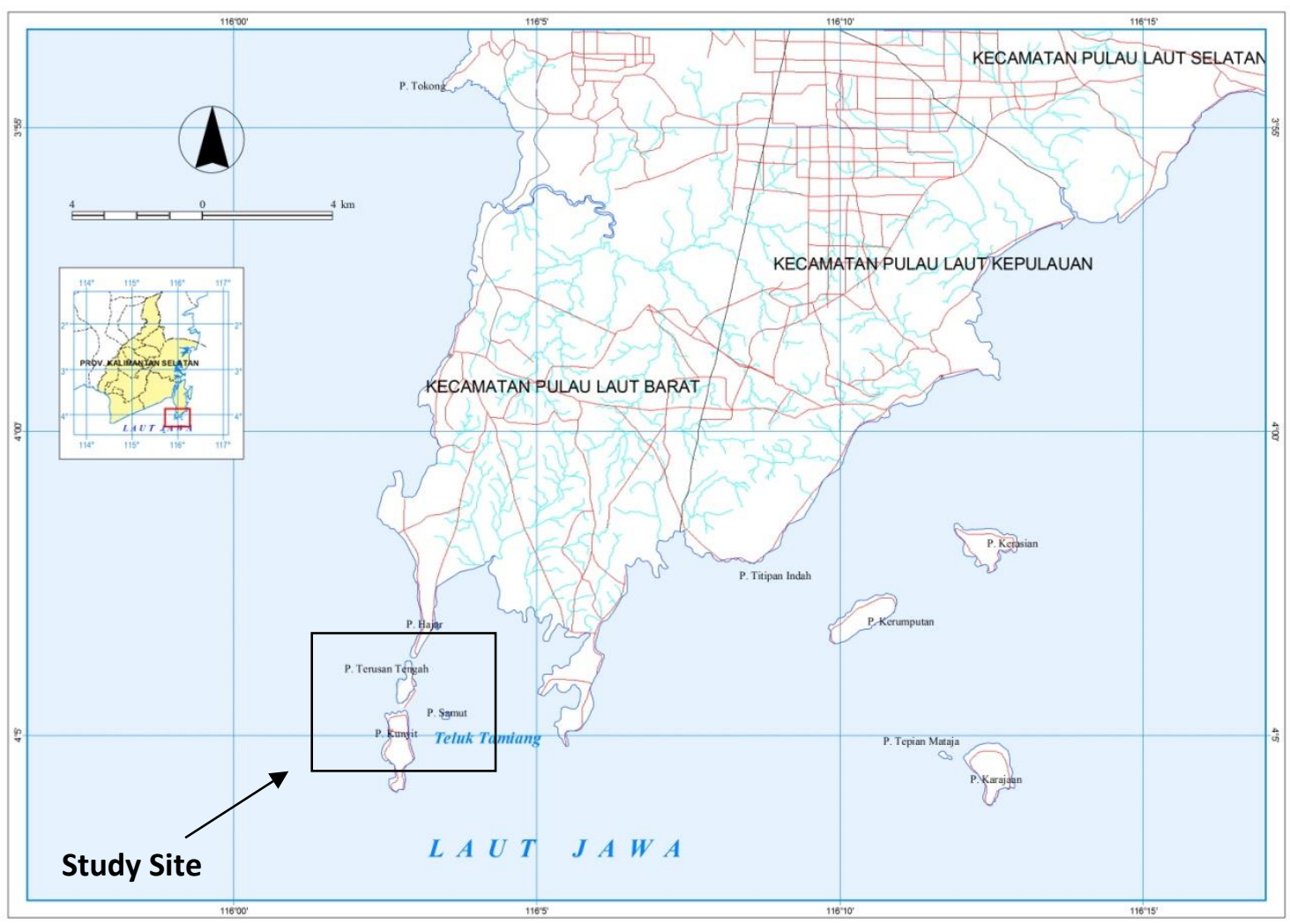

Figure 1 Map of Study Site

Station Determination. There were two study stations where the regional distribution of macroalgae took place. Each station had 3 Substations. In each station were placed 3 transects representing a variety of water depth.

Data Collection. Macroalgae sampling was conducted at each observation station using quadrant transect of $1 \times 1 \mathrm{~m}, 3$ transects for each station with grid of $20 \times 20 \mathrm{~cm}$ and interval between transects of $5 \mathrm{~m}$. Data were collected by a systematic sampling method. This method aimed at observing the condition of the distribution and macroalgal cover in coral reef ecosystems. Macroalgae species found were recorded and the macroalgae colonies were measured by measuring the length and width of the colonies in the model of a square in one grid with a level of accuracy approaching centimeters (English, 1997). For uniformity, one colony was considered a single individual.

When a colony of the same species was separated by another colony, each separate part was regarded as a separate individual. When two or more colonies grew among the other colonies, each colony was still counted as a separate colony. The basic condition and the presence of substrate found at the site were also recorded. Data collection of environmental parameters was carried out before sampling at each observation transect. The supporting parameters measured include: temperature, salinity, and depth as well as sea water sample to measure the concentration of nitrate and phosphate.

Data processing. Data processing of microalgae includes Macroalgae distribution, structure of microalgae community (density, 
Macroalgae covers, composition of species), and diversity index and uniformity index. The observation of macroalgae distribution was carried out based on the identification results of macroalgae both in the field and in the laboratory on the distribution of macroalgae species in coral reef ecosystem.

Macroalgae density was determined using a quadrant transect method. Data were collected by placing three transect quadrant of 1 $\mathrm{x} 1 \mathrm{~m}$ at intervals of $25 \mathrm{~m}$ at each station. The number of colonies of each macroalgae species in the area of transect were then count. Data of macroalgae density were obtained using the formula by Brower et al. (1998), namely:

$$
\mathrm{D}=\frac{\mathrm{n}_{\mathrm{i}}}{\mathrm{A}}
$$

Where :

$\mathrm{D}=$ Density of macroalgae species (colony $/ \mathrm{m}^{2}$ ) $\mathrm{n}=$ Number of colony each macroalgae species (colony)

$A=$ Width of transect $\left(m^{2}\right)$

Estimation of macroalgal cover percentage was done using the estimation developed by Atobe (1970) in English (1994), with the transect of $1 \times 1$ meters and grid of 20 $x 20 \mathrm{~cm}$. The scales used for the categories of each grid were $1 / 4,1 / 2,3 / 4$ and 1 unit.

The percentage of the cover was calculated using the following equation:

$$
\mathrm{C}=\frac{\sum\left(C_{i}\right)}{\mathrm{A}} \times 100 \%
$$

where:

$\mathrm{C}=$ Percentage of cover

$\Sigma \mathrm{Ci}=$ Number of cover units of each grid of each macroalgae species

$A=$ Number of total used grids (25 units)

The species composition was determined by calculating the density of each species of macroalgae, and compared to find out the percentage of the number of all species of macroalgae. To calculate the composition of macroalgae species, the following formula (Odum, 1971) was used:

$$
\mathrm{KJ}=\frac{\mathrm{n}_{\mathrm{i}}}{\mathrm{N}} \times 100
$$

Where:

$\mathrm{ni}=$ Number of each Macroalgae species observed

$\mathrm{N}=$ Jumlah koloni seluruh species

Diversity index was calculated using the Shannon-Wiener formula (Krebs, 1993). Uniformity index was calculated using the Evenness formula (Krebs, 1993). Value Range of Diversity and Uniformity Index as well as the estimating category using Law criteria, 1996. Macroalgae samples were identified in the Laboratory of Bioecology, Sea Marine Science Department, Lambung Mangkurat University, Banjarmasin, using stereomicroscope tools and a book of macroalgae identification (Aslan, 1991.1998)), (Atmadja, 1988), (FAO, 1998), (Jha 2009), (Junaeidi, 2004), (Kadi \& Atmajaya, 1998) and (Wanda, 1988).

Data Analysis. Macroalgae distribution of each species was determined by observing the habitat of each species while the cover, density and composition of each species of macroalgae will be differentiated based on each station using student-T test, assisted with SPSS version 18.0

\section{RESULTS AND DISCUSSION}

Distribution of macroalgae at the waters of Teluk Tamiang Village tended to be higher in the east than in the west of the region. The closer to the mainland, the greater the macroalgal cover. The map of macroalgae distribution is shown in the following table: 
Table 1 Distribution of macroalgae at the waters of Teluk Tamiang Village

\begin{tabular}{|c|c|c|c|c|c|c|c|c|}
\hline \multirow{3}{*}{ Transect } & \multicolumn{8}{|c|}{ Distribution of Macroalgae (\%) } \\
\hline & \multicolumn{4}{|c|}{ Station I (East) } & \multicolumn{4}{|c|}{ Station II (West) } \\
\hline & 1 & 2 & 3 & Average & 1 & 2 & 3 & Average \\
\hline $1(0-2 m)$ & 32.1 & 29.4 & 34.8 & 32.1 & 22.4 & 26 & 24.2 & 24.2 \\
\hline $2(2-4 m)$ & 28.5 & 33.6 & 30.2 & 30.8 & 20.5 & 25.6 & 22.4 & 22.8 \\
\hline $3(4-6 m)$ & 31.3 & 26.8 & 18.4 & 25.5 & 21.7 & 22.1 & 23.8 & 22.5 \\
\hline Average & 30.63 & 29.93 & 27.80 & & 21.53 & 24.57 & 23.47 & \\
\hline Total & \multicolumn{4}{|c|}{88.37} & \multicolumn{4}{|c|}{69.57} \\
\hline Average & \multicolumn{4}{|c|}{29.46} & \multicolumn{4}{|c|}{23.19} \\
\hline
\end{tabular}

The distribution showed that the highest average macroalgal cover was found at the waters of the East (Station I), higher than that in the western (Station II). The eastern part is in the bay area while the western directly faced the Java Sea and the Makassar Strait. The high macroalgal cover at Station I was due to the high supply of nutrients from the land trapped in the bay area. The land is the main supplier of organic materials that can improve the fertility of waters (McCook, 2001; Edinger, et al., 1998).

Cover variation was seen at different depth of waters. The waters more shallow and adjacent to the land had the higher average cover than the deeper waters toward the ocean.

The number of macroalgae found in the coral reef habitat is presented in Figure 2. There were 8 macroalgae species of coral reef ecosystem found, which were derived from 7 order, 8 family, and 8 genera. Macroalgae from the Rhodophyceae and Chlorophyceae classes were the most species found, namely three species of the Rhodophyceae class consisting of Acanthopora muscoides, Gracilaria coronopifolia, and Amphiroa fragillissima, and three species of the Chlorophyceae class, Chlorodesmis sp., Halimeda macroloba and Enteromorpha sp. Macroalgae species from the Phaeophyceae class were the lowest species with two species, Turbinaria conoides and Dictyota pinnatifida. The result of T-student test $(95 \%(\alpha=0.05))$ indicated there was no significant different between the species composition of macroalgae at Station I and Station II in the coral reef ecosystem.

Ecological indices such as diversity index $\left(\mathrm{H}^{\prime}\right)$ and uniformity index $(\mathrm{E})$ of macroalgae at each station at the waters of Teluk Tamiang Village are presented in Figure 3.
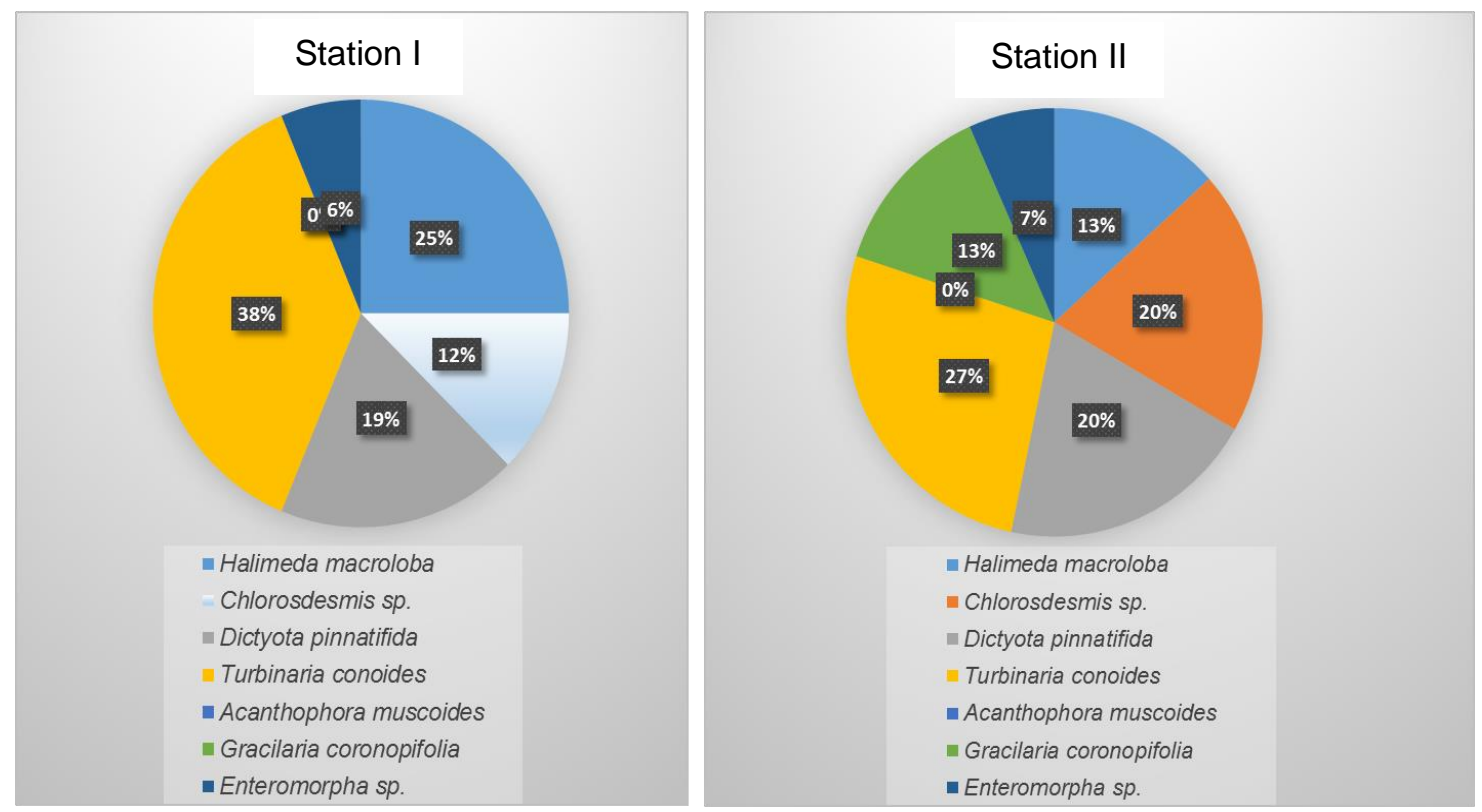

Figure 2 Number of macroalgae species in the coral reef ecosystem 


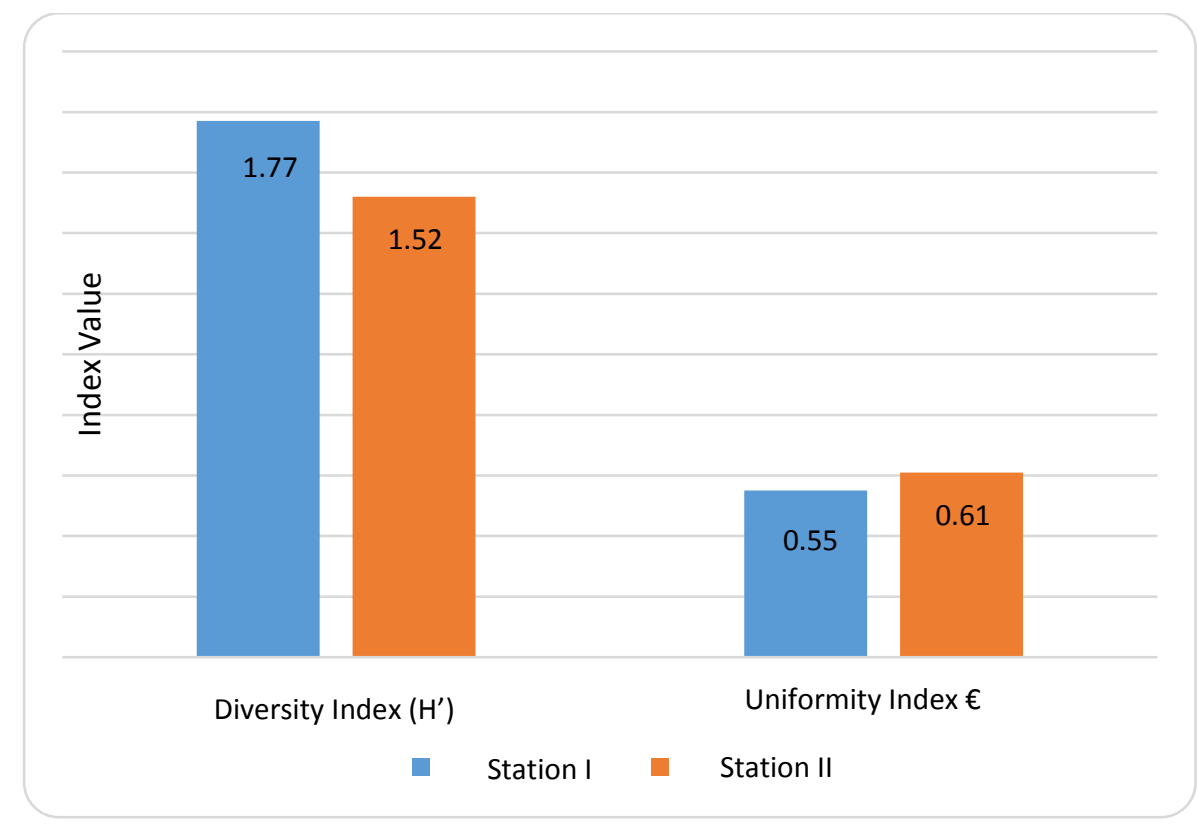

Figure 3 Structure of macroalgae community at the waters of Teluk Tamiang Village

The value of diversity index $\left(\mathrm{H}^{\prime}\right)$ in the coral reef ecosystem at the waters of Teluk Tamiang was categorized low, ranging from 1.52 to 1.77 . The lowest diversity index was obtained in Station II, while the highest in Station I.

\section{CONCLUSIONS}

Eight species of macroalgae were found in the coral reef ecosystem, which were derived from 7 order, 8 family, 8 genera, consisting of Acanthopora muscoides, Gracilaria coronopifolia, and Amphiroa fragillissima Chlorodesmis sp., Halimeda macroloba and Enteromorpha sp., Turbinaria conoides and Dictyota pinnatifida. The diversity index in two observed stations was relatively low.

\section{REFERENCES}

Aslan, L.M., (1991), (1998). Seaweed Cultivation. Kanissius Yogyakarta.

Atmajaya, W.S. (1999). Distribution and Some Aspects of Seaweed (Macroalgae) Vegetation in Coral Reefs, Indonesia. Puslitbang Oceanology-LIPI. Jakarta.
Hukom, F.M. (1998). Spatio-temporal Ecostructure and Organization of Coral Fish at the waters of Teluk Ambon. Thesis. Graduate Program, IPB Bogor.

Hutabarat, S. and Evans, S.M. (1985). Introduction to Oceanography. UI Press. Jakarta.

lqbal, M. (2008). Community Structure and Distribution of Macroalgae. Their relationship with Oceanographic Conditions at the Waters of Lae-lae Island, Makassar. Department of Marine Sciences, University of Hasanuddin. Makassar.

Jha, B., Reddy, C.R.K., Thakur, M.C. and Rao, M. U. (2009). Seaweeds of India. The Diversity and Distribution of Seaweed of Gujarat Coast. New York.

Kadi, and Atmajaya, W.S. (1988). Seaweed (Algae), Species, Reproduction, Production, Cultivation and Post Harvest. LIPI. Jakarta.

Kadi, A. (1999). Some Notes about Gelidium (Rhodophyta).

Puslitbang 